\title{
METHODOLOGY OF TOXICOLOGICAL EFFECTS ASSESSMENT IN AQUATIC ECOSYSTEMS BY BIODIVERSITY INDICATORS USE
}

\author{
Oleh SKYDAN, Zhytomyr National Agroecological University, Staryi Blvd 7, Zhytomyr, 10008 Ukraine, skydanolegv@ukr.net \\ Tetiana FEDONIUK, Educational and scientific center of ecology and environmental protection, Zhytomyr National Agroecological \\ University, Staryi blvd., 7, Zhytomyr, 10008 Ukraine, tanyavasiluk2015@ gmail.com (corresponding author) \\ Roman FEDONYUK, Department of Forest Ecology and Life Safety, Zhytomyr National Agroecological University, Staryi Blvd 7, \\ Zhytomyr, 10008 Ukraine, rfedonyk@gmail.com
}

\begin{abstract}
The implementation of the EU Water Framework Directive 2000/60/EC within Eastern European is now becoming of utmost significance. This is especially relevant to the territory of Ukrainian Polessie, which is characterized by specific geological and geomorphological conditions, excessive humidification and significant anthropogenic pressure on all components of ecosystems. In this section, we present a methodology for evaluating the content of specific toxicological substances based on a diversitological approach to the macrophyte composition of reservoirs. At the same time, the possibility to apply diversisologic indicators for the bio-indication of the content of heavy metals in coastal soils and bottom deposits was assessed. The most striking changes in the species composition are manifested at the points of the most significant anthropogenic pressure in the presence of toxic compounds in aquatic ecosystems. Significant variations in view indices were noted when the high concentration of heavy metals was reached in the bottom soil. The most significant influence on the species composition is due to high concentrations of the active forms of zinc and cuprum cations in both coastal soils and bottom deposits, although the excessive maximum limits allowed were only in the second group of substances. The close correlation between the content of all investigated groups of heavy metals in bottom deposits and species numbers, the index of dominance, Shannon Diversity Index, and Pielou's Evenness Index were established. For Margalef Species Richness Index, close dependencies were established for active forms of cations of nickel, cobalt, zinc and cadmium, for other groups the bonds were weak. For Sørensen-Dice Index weaknesses were found with the contents of active forms of cations of nickel and chromium; for other groups of active forms of heavy metals, except cobalt cations, close ties were established as well.
\end{abstract}

Keyworlds: diversitology, macrophytes, surface waters, heavy metals.

\section{INTRODUCTION}

The increase of anthropogenic load, levels of consumption of natural water, extensive type of management in the basins of the rivers of Ukrainian Polessie not only caused the deterioration of the ecological state of surface waters, but also led to significant changes in the composition and state of the biota (Romanchuk et al., 2018; Fedoniuk, 2018). Modern methods for assessing the quality of water that are used by the controlling service agencies come down to establishing the presence of certain levels of toxic substances in water, while their impact on a number of reservoir inhabitants is negated. In recent years, the necessity and significance of strategic level operations aimed at ensuring an integrated evaluation of the ecological stability of water ecosystems is increasing (Cao et al., 1996). Such integrated evaluation is set out by the EU Water Framework Directive 2000/60/EC. However, within Eastern Europe, including the Polessie region, which is characterized by specific geological, geomorphological and climate conditions, as well as intensive anthropogenic pressure on all components of ecosystems, it requires significant adjustments, which involve increasing the role of the biological component in particular, expanding the list of biological indicators that are suitable for inclusion in the system of integrated evaluation of the surface water quality (Romanchuck et al., 2017; Elmqvist et al., 2003). One of the most worthwhile groups for phytomonitoring, i.e. evaluation of the state of the environment according to botanical features, are macrophytes, that is, large algae, mosses and vascular plants, which normally develop under the conditions of the water environment and excessive humidification and also exist both in water and in the coastal zone (which also belongs to the ecosystem of reservoirs) (Muxika \& Bald, 2007; Rai et al., 1995; Miretzky et al., 2004; Zhukova \& Mastitskii, 2014; Mishra et al., 2008).

In this section, we considered the issue of developing theoretical and methodological principles for the use of delayed bio-monitoring of aquatic ecosystems based on the assessment of the stability of hydrobiont development as the main vector of implementation of the EU Water Framework Directive 2000/60/EC. In addition, the parameters of the functioning of the aquatic ecosystems of the Ukrainian Polessie, which determine the general differentiation of indicators of water quality as well as structural and functional features of the macrophytes species in the aquatic ecosystems of the Ukrainian Polessie, were identified. Moreover, their division according to the relation to ecological factors of the environment was carried out; and also the main criteria for conducting the delayed bio-monitoring, which is based on the

Copyright (C) 2019 The Authors. Published by Vytautas Magnus University. This is an open-access article distributed under the terms of the Creative Commons Attribution License (CC BY 4.0), which permits unrestricted use, distribution, and reproduction in any medium, provided the original author and source are credited. 
analysis of the dynamics of the species composition of phytocoenosis using the species recording criteria, were specified (Munné et al., 2003; Logan \& Furse, 2002; Didukh \& Pliuta, 1994).

Thus, changes can occur even under minimal contamination, which cannot be detected by chemical or bacteriological methods. Although Bunn \& Arthington (2002), Gotelli \& Colwell (2001) and other scientists argue that aquatic macrophytes are characterized by conservatism regarding the short-term fluctuation changes in the environment. However, directed vegetation changes for several years, such as degree and nature of the reservoir overgrowth, floristic composition, the development of phytomass and macrophyte products, and their chemical composition, may indicate the transformation of the ecosystem and the change in the water quality, which is the point to note. Hence, macrophytes are a significant object for many years of observation.

Savytska (2014) notes that the high content of salts of heavy metals is one of the most important stress-inducing factors of influence on phytocenosis. The analysis of literary sources allowed to form a ranked number of toxicity of heavy metals in relation to them (in descending order): $\mathrm{Cu} \rightarrow \mathrm{Ni} \rightarrow \mathrm{Cd} \rightarrow \mathrm{Zn} \rightarrow \mathrm{Pb} \rightarrow \mathrm{Hg} \rightarrow \mathrm{Fe} \rightarrow \mathrm{Mo} \rightarrow \mathrm{Mn}$ (Kovalchuk, 2012).

\section{METHODOLOGY OF THE EXPERIMENT ON SHORT-TERM BIOINDICATION OF AQUATIC ECOSYSTEMS}

The study of the possibilities of using the morphogenetic approach in determining the ecological tolerance and the stability of the development of aquatic ecosystems was determined under the conditions of the Ukrainian Polessie zone. Among various types of reservoirs, rivers belonging to the class of medium and large watercourses - Teterev, Gnilopyat, Irsha, Guyva and Zdvizh - flowing through the territory of Zhytomyr and Kyiv regions were chosen, as well as fairly large reservoirs - Chudniv, Otsechnoye, Zhytomyr, Malyn and Irshansk (Fig. 1).

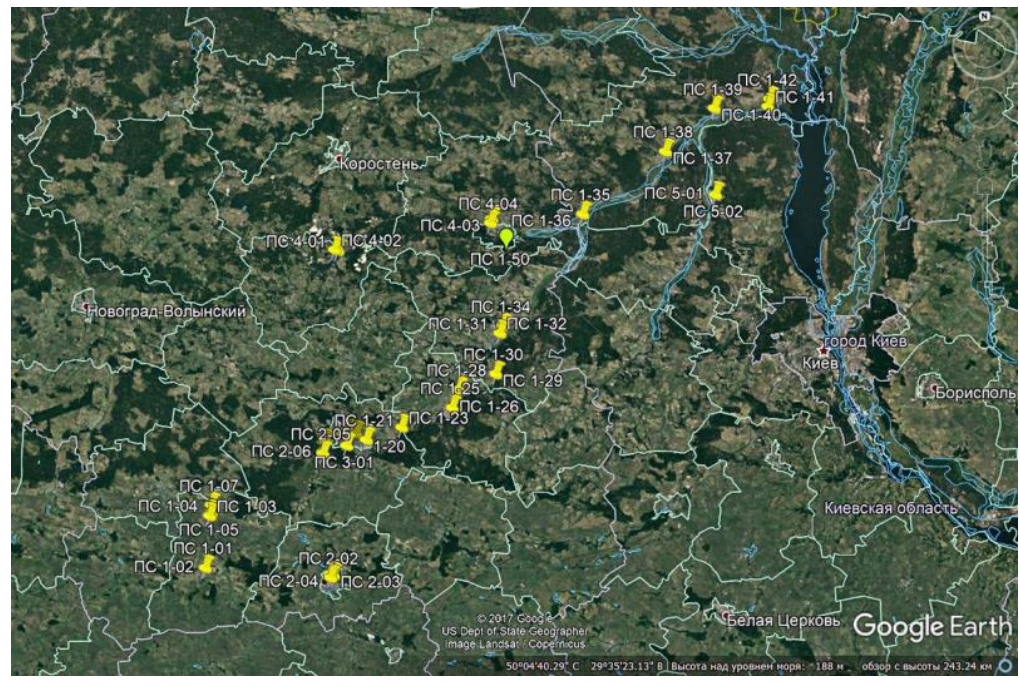

Figure 1. Distribution of registration points of higher aquatic vegetation on the territory of Ukrainian Polessie

The water quality at the observation points was assessed in accordance with the "Methodology for the environmental assessment of surface water quality according to relevant categories". Therewith, 43 indicators of the physical and chemical composition of water were determined. According to the obtained data, the overall water quality index WQI was calculated as the average of three block indices: SI - the Salt Index; TSI - index of trophy-saprobological indicators; TI - index of the content of specific toxic and radiation substances.

During the research, the application of the method of short-term bioindication was tested, according to which geobotanical descriptions of groups of higher aquatic plants and evaluation of the data obtained using a morphogenetic approach were carried out. The primary materials for the bioindication analysis were independent studies of the authors, which included descriptions of aquatic ecosystems of certain parts of the river ecosystems of Ukrainian Polessie. The authors collected the materials during 2011 - 2015. The research was carried out at 57 points simultaneously with water sampling. For a more detailed analysis of the anthropogenic impact on the species composition of macrophytes, the samples were also taken along the river before and after the territories of settlements.

The basis for assessing the state of disturbed ecosystems and comparing them with background objects were the main indicators of diversity: species wealth, species number, alignment, similarity, dominancy index and diversity index (Magurran, 2013; Nagendra, 2002; Raspopov, 2000; Spellerberg, 2005).

\section{BIOIDENTIFICATION OF THE CONTENT OF SPECIFIC TOXIC AND RADIOLOGICAL SUBSTANCES IN BOTTOM DEPOSITS AND COASTAL SOILS}

The variation in the content of the mobile forms of $\mathrm{Zn}^{2+}$ cations in the coastal soils of the Teteriv ecological corridor is in the range from 3.0 to $14.7 \mathrm{mg} / \mathrm{kg}$, which in general does not exceed the established standards. The average content 
of mobile forms of $\mathrm{Zn}^{2+}$ cations in the basin of the Teteriv River is $7.139 \pm 3.5988 \mathrm{mg} / \mathrm{kg}$.

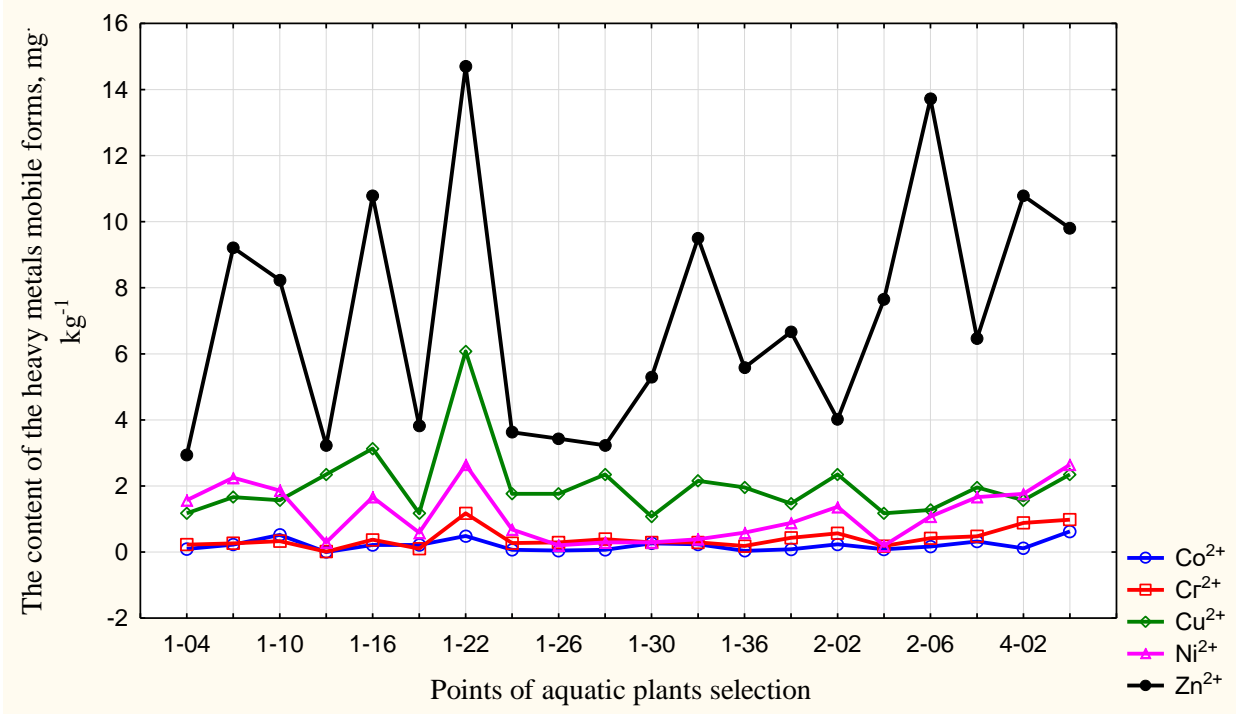

Figure 2. The content of the mobile forms of heavy metals in the coastal soils at some points of selection of aquatic plants, $\mathrm{mg} / \mathrm{kg}$ of soil

The most critical points regarding the content of this pollutant were points number $1-16,1-22,2-06$ and 4-06, that is, those areas that were exposed to sewage in Zhytomyr, Berdychiv, Malyn and the mouth of the Kamenka River, which brings a considerable amount of pollutants to the Teterev River with wastewater and land runoffs in Zhytomyr (Fig. 2). The content of the $\mathrm{Cu}^{2+}$ mobile forms in the coastal soils of the Teteriv River and some of its feeders ranged from 1.078 to $6.076 \mathrm{mg} / \mathrm{kg}$, which partially corresponded to the established MAC for this pollutant (3 mg/kg). The average value in the basin of the Teteriv River during the research period amounted to $2.019 \pm 1.0933 \mathrm{mg} / \mathrm{kg}$. The most critical areas regarding the content of heavy metals were points number $1-16,1-22$, that is, areas of excessive anthropogenic pressure in Zhytomyr.

According to the research data, the content of mobile forms of nickel in the coastal soils varied in the range from 0.196 to $2.646 \mathrm{mg} / \mathrm{kg}$, which fully corresponds to the established MAC for this pollutant. The average value in the basin of the Teteriv River was $1.147 \pm 0.8218 \mathrm{mg} / \mathrm{kg}$. The most critical sites regarding the content of heavy metals were the points number $1-08,1-16,1-22,4-06$, that is, the same sites that were exposed to the influence of sewage in Chudniv, Zhytomyr, Berdychiv and the mouth of the The Kamenka River, which was marked by the increased content of other groups of pollutants.

The content of mobile forms of cobalt cations in the coastal soils of the Teteriv River and some of its feeders varied from 0.002 to $0.627 \mathrm{mg} / \mathrm{kg}$, which fully corresponded to the established MAC for this pollutant $(5 \mathrm{mg} / \mathrm{kg})$. The average value in the basin of the Teteriv River amounted to $0.206 \pm 0.1714 \mathrm{mg} / \mathrm{kg}$. The highest concentrations of cobalt cations were found at the points 1-10,1-22, 4-06, although there, this figure was almost 10 times lower than the established MAC.

The content of the mobile forms of chromium cations also did not exceed MAC. Its indicators ranged from 0.010 to $1.176 \mathrm{mg} / \mathrm{kg}$, and the average value in the basin of the Teteriv River was $0.407 \pm 0.2947 \mathrm{mg} / \mathrm{kg}$. The highest concentrations of cobalt cations were found at the points 1-22, 4-02, 4-06.

There are dependencies of various degree of density between the content of mobile forms of heavy metals and the main criteria of biodiversity (Table 1). It should also be noted that most of the investigated indicators regarding the content of heavy metals have an inverse dependence on biodiversity indicators. However, the inverse relationship between them has a different nature. Thus, the Margalef index of species richness (d) decreased when the concentration of $\mathrm{Cu}^{2+}$ and $\mathrm{Zn}^{2+}$ in coastal soils increased, which is confirmed by inverse correlation dependencies with $r=-0.290$ and $r=-0.598$, respectively. However, in the distribution of the Margalef indices of species richness, depending on the concentration of $\mathrm{Cu}^{2+}$, this dependence was weak. Thus, there were no clear trends in the distribution of mobile forms of $\mathrm{Cu}^{2+}$ up to the limit of the established MAC ( $\left.3 \mathrm{mg} / \mathrm{kg}\right), \mathrm{but}$ in the phytocoenosis contaminated by this pollutant above the MAC, the Margalef index was reduced by more than 2.5 times. Therefore, one can testify to the negative influence of mobile forms of $\mathrm{Cu}^{2+}$ in the coastal soils on the Margalef index only in concentrations exceeding the MAC.

In the distribution of the values of the Margalef indices of the species richness up to the limit of $8 \mathrm{mg} / \mathrm{kg}$ for $\mathrm{Zn}^{2+}$ there were no clear trends for the variation of values; however, it was noted that the value of this indicator decreased when the concentration of mobile zinc forms rose above $8 \mathrm{mg} / \mathrm{kg}$. In particular, this range accounted for $40 \%$ of the points, of which none showed value d exceeding 10. And hence, one can testify to the negative effect of $\mathrm{Zn}^{2+}$ content in the concentration above $8 \mathrm{mg} / \mathrm{kg}$, although the corresponding MAC is $23 \mathrm{mg} / \mathrm{kg}$.

The Simpson's index of dominance (c) turned out to be sensitive to the same groups of pollutants, which established close straight-line correlation dependencies: $r=0.376$ for $\mathrm{Cu}^{2+}$ and $\mathrm{r}=0.550$ for $\mathrm{Zn}^{2+}$. A weak correlation dependence of this index with the content of $\mathrm{Cr}^{2+}(\mathrm{r}=0.305)$ was established. 
Table 1. Values of correlation coefficients between the concentration of heavy metals in the coastal soils and bioindication indicators

\begin{tabular}{|c|c|c|c|c|c|c|c|c|c|c|c|c|c|c|c|}
\hline \multirow[b]{2}{*}{ 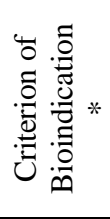 } & \multicolumn{3}{|c|}{$\mathrm{Co}^{2+}$} & \multicolumn{3}{|c|}{$\mathrm{Cr}^{2+}$} & \multicolumn{3}{|c|}{$\mathrm{Cu}^{2+}$} & \multicolumn{3}{|c|}{$\mathrm{Ni}^{2+}$} & \multicolumn{3}{|c|}{$\mathrm{Zn}^{2+}$} \\
\hline & - & 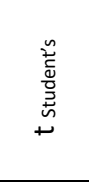 & 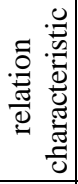 & - & 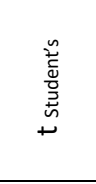 & 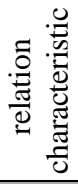 & - & 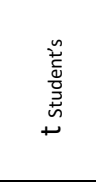 & 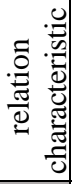 & - & 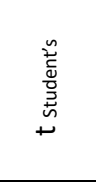 & 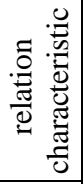 & - & 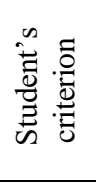 & 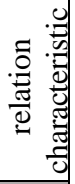 \\
\hline $\mathrm{d}$ & -0.136 & -1.010 & - & -0.275 & -2.099 & + & -0.290 & -2.223 & + & -0.194 & -1.452 & - & -0.598 & -5.486 & + \\
\hline $\mathrm{c}$ & 0.020 & 0.148 & - & 0.305 & 2.352 & + & 0.376 & 2.980 & + & 0.057 & 0.418 & - & 0.550 & 4.838 & + \\
\hline $\mathrm{i}$ & -0.248 & -1.882 & - & -0.118 & 0.872 & - & 0.206 & 1.548 & - & -0.292 & 2.246 & + & -0.035 & 0.256 & - \\
\hline $\mathrm{H}$ & 0.018 & 0.129 & - & -0.237 & -1.790 & - & -0.292 & -2.247 & + & 0.018 & 0.133 & - & -0.439 & -3.595 & + \\
\hline $\mathrm{E}$ & 0.010 & 0.073 & - & -0.143 & -1.062 & - & -0.171 & -1.277 & - & 0.105 & 0.777 & - & -0.410 & -3.298 & + \\
\hline
\end{tabular}

Note: the value of the relation $\mathrm{r}$ on the performance of an attribute is equal to the critical tabular value for $\mathrm{n}=80 \mathrm{t}$ Student's $=1.99$. $*$ The Margalef index of species richness - d; Simpson's index of dominance - c, Sørensen-Dice index - i, Shannon diversity index - H, Pielou's evennes index - E.

The distribution of the values of the Simpson's indices of dominance in the range from 0.8 to 0.13 occurred exclusively in the areas of the coastal soil with the concentration of $\mathrm{Zn}^{2+}$ below $8 \mathrm{mg} / \mathrm{kg}$, in the following range c from 0.13 to 0.20 . Clear distributions of the $\mathrm{Zn}^{2+}$ concentration were not observed. However, it should be noted that the worst values $\mathrm{c}$ are characteristic of the concentrations of $\mathrm{Zn}^{2+}$ amounting to $13 \mathrm{mg} / \mathrm{kg}$ and above; i.e. like the Margalef index, the Simpson's index of dominance indicates the sensitivity of the indicators of species diversity to the concentration of $\mathrm{Zn}^{2+}$ in the coastal soil, which is almost twice lower than the corresponding MAC.

No clear dependence was observed in the distribution of $\mathrm{c}$ values depending on the presence of $\mathrm{Cu}^{2+}$ in the coastal soil with the concentration below $4 \mathrm{mg} / \mathrm{kg}$. However, with an increase in the concentration of $\mathrm{Cu}^{2+}$ above MAC, there was a more significant predominance of dominant kinds of macrophytes that are hyposensitive to the content of heavy metals in the environment. In view of this, one can expect a c increase in reaction to the increase of $\mathrm{Cu}^{2+}$ content above the value of MAC. A similar distribution is also characteristic of $\mathrm{Cr}^{2+}$, where the negative effect is mainly manifested only in places with the approximation of its concentration to $1.0 \mathrm{mg} / \mathrm{kg}$. However, taking into account the small number of points where the concentration amounted to $1.0 \mathrm{mg} / \mathrm{kg}$ or above and the weak degree of correlation dependence, this should be considered an assumption rather than an axiom.

The Shannon Diversity Index $(\mathrm{H})$ also turned out to be sensitive to the same groups of pollutants, which established close inverse correlation dependencies: $r=-0.292$ for $\mathrm{Cu}^{2+}$ and $r=-0.439$ for $\mathrm{Zn}^{2+}$. Since the calculations of the Shannon diversity index are calculated on the basis of the same data as the Simpson's index of dominance, the tendencies of the $\mathrm{H}$ distribution are generally reversed to the c distribution. And, therefore, this indicator is also characterised by the tendencies towards the significant variability of the indicators in the value ranges of $\mathrm{Zn}^{2+}$ in the coastal soil are almost two times lower than the corresponding $\mathrm{MAC}, \mathrm{Cu}^{2+}$ and $\mathrm{Cr}^{2+}$ values are close to the corresponding MAC.

A close inverse relation is also observed for the Pielou's evenness index with the concentrations of $\mathrm{Zn}^{2+}$ mobile forms in the coastal soil. In particular, the trends, which are characteristic of other indicators of species diversity, were present here. No clear dependence of the Pielou's evenness index was detected below the concentration level of $12 \mathrm{mg} / \mathrm{kg}$. However, the excess of this limit caused the movement of Pielou's evenness indices from the range of 0.8-1.1 to the range of 0.6-0.7.

The Sørensen-Dice index was the least sensitive to the toxic action of heavy metals in the coastal soil. It was indicative of only the content of nickel, although that relation was defined as "weak".

\section{BIOIDENTIFICATION OF THE CONTENT OF SPECIFIC TOXIC AND RADIOLOGICAL SUBSTANCES IN BOTTOM DEPOSITS AND COASTAL SOILS}

The variation in the content of the mobile forms of zinc cations in the bottom deposits of the Teterev ecological corridor is in the range from 1.176 to $49.000 \mathrm{mg} / \mathrm{kg}$, which exceeds the established standards in the point number $1-22$. The average content of mobile forms of zinc cations in the bottom deposits of the Teteriv River and some of its feeders amounted to $9.150 \pm 11.2567 \mathrm{mg} / \mathrm{kg}$. The high content of mobile forms of $\mathrm{Zn}^{2+}$ compared to the statistically average values across the basin of the Teteriv River was identified in the points $1-04,1-10,1-16,1-34,2-06$ and others (fig. 3).

The content of the $\mathrm{Cu}^{2+}$ mobile forms in the bottom deposits of the Teteriv River and some of its feeders ranged from 0.980 to $5.880 \mathrm{mg} / \mathrm{kg}$, which partially corresponded to the established MAC for this pollutant (3 mg/kg). The average value in the basin of the Teteriv River according to the data of 2011-2013 amounted to $1.929 \pm 1.1391 \mathrm{mg} / \mathrm{kg}$. The most critical areas regarding the content of $\mathrm{Cu}^{2+}$ were points 1-22 and 1-34, that is, areas of excessive anthropogenic pressure in Zhytomyr and Radomyshl.

According to the research data, the content of $\mathrm{Ni}^{2+}$ mobile forms in the bottom deposits of the Teteriv River and its feeders varied in the range from 0.294 to $3.332 \mathrm{mg} / \mathrm{kg}$, which fully corresponds to the established MAC for this pollutant. The average value in the basin of the Teteriv River was $1.190 \pm 0.9540 \mathrm{mg} / \mathrm{kg}$. 


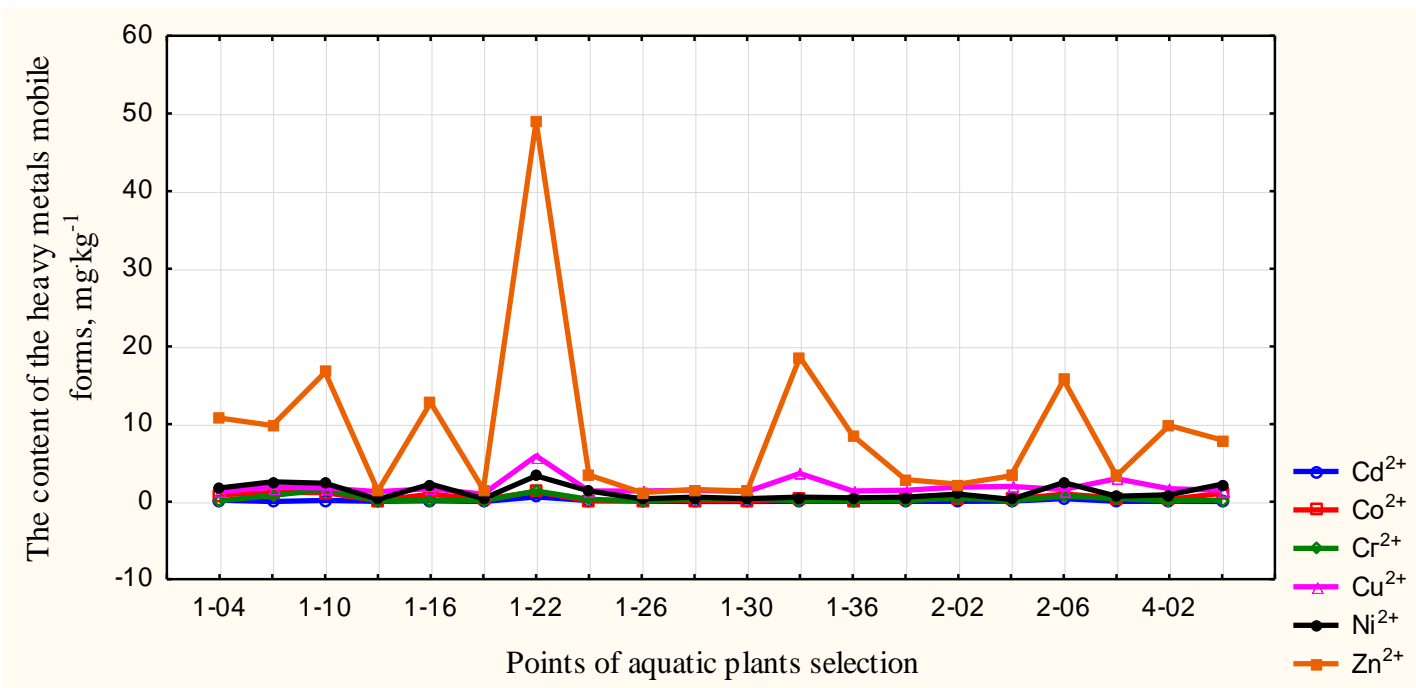

Figure 3. The content of the mobile forms of heavy metals in the bottom deposits at some points of selection of aquatic plants

The most critical areas regarding the content of heavy metals were points $1-08,1-10,1-22,2-06,4-06$, that is, the same critical sites that are connected with the influence of sewage in Chudniv, Zhytomyr, Malyn, and Berdychiv.

The content of $\mathrm{Co}^{2+}$ mobile forms in the bottom deposits of the Teteriv River and some of its feeders varied from 0.098 to $1.274 \mathrm{mg} / \mathrm{kg}$, which fully corresponded to the established MAC for this pollutant $(5 \mathrm{mg} / \mathrm{kg})$. The average value in the basin of the Teteriv River amounted to $0.509 \pm 0.4186 \mathrm{mg} / \mathrm{kg}$. The highest concentrations of cobalt cations were found at the same points as previous pollutant.

The content of the mobile forms of chromium cations also did not exceed MAC. Its indicators ranged from 0.098 to $1.568 \mathrm{mg} / \mathrm{kg}$. The average value in the basin of the Teteriv River was $0.387 \pm 0.4364 \mathrm{mg} / \mathrm{kg}$. The highest concentrations of $\mathrm{Co}^{2+}$ mobile forms were found at the points $1-10$ and $1-22$.

The content of the mobile forms of chromium and cadmium cations also did not exceed MAC. Their indicators ranged from 0.098 to $1.568 \mathrm{mg} / \mathrm{kg}$ and from 0.020 to $0.598 \mathrm{mg} / \mathrm{kg}$, respectively. The average values in the basin of the Teteriv River were $0.387 \pm 0.4364 \mathrm{mg} / \mathrm{kg}$ for chromium cations and $0.106 \pm 0.1496 \mathrm{mg} / \mathrm{kg}$ for cadmium cations. The highest concentrations of $\mathrm{Co}^{2+}$ were found at the points 1-10 and 1-22, while points 1-10 and 2-06 showed the highest concentration of cadmium.

There are various dependencies between the content of mobile forms of heavy metals in the bottom deposits and the main criteria of biodiversity (Table 2). A close inverse relation with the $\mathrm{Zn}^{2+}$ content was identified for the Margalef index of species richness $(\mathrm{r}=-0.497)$. Thus, at the level of $\mathrm{Zn}^{2+}$ pollution from 0 to $10 \mathrm{mg} / \mathrm{kg}$ the index values ranged from 8 to 17 , while with the increase of its concentration the $d$ range shifted to 5-13. It should be noted that the worst $d$ values were recorded when the level of pollution exceeded $15 \mathrm{mg} / \mathrm{kg}$. Hence, $\mathrm{Zn}^{2+}$ content with the concentration level that exceeds $10 \mathrm{mg} / \mathrm{kg}$ causes the decrease of the Margalef index by 1.5 times.

Certain trends were observed in the distribution of points according to the level of pollution with other heavy metals. Thus, a significant decrease of $\mathrm{d}$ caused the following concentrations of the content in the bottom deposits: $\mathrm{Ni}^{2+}$ - above $2 \mathrm{mg} / \mathrm{kg}(\mathrm{r}=-0.396), \mathrm{Co}^{2+}-0.8 \mathrm{mg} / \mathrm{kg}(\mathrm{r}=-0.340), \mathrm{Cu}^{2+}-$ above $3 \mathrm{mg} / \mathrm{kg}(\mathrm{r}=-0.396), \mathrm{Co}^{2+}-0.8 \mathrm{mg} / \mathrm{kg}$ $(r=-0.340), \mathrm{Cu}^{2+}-$ above $3 \mathrm{mg} / \mathrm{kg}(r=-0.290), \mathrm{Cd}^{2+}-0,3 \mathrm{mg} / \mathrm{kg}(r=-0.404)$. However, the established correlation dependencies between the Margalef index of species richness and the content of mobile forms of cobalt were marked by low significance value of correlation relation. In view of this, they were described as "weak", which is connected to a limited number of points with the level of pollution with the mentioned heavy metals above MAC.

The situation with the distribution of the Simpson's index is different. Tight straight-line connections with high levels of significance with the content of mobile forms of cadmium, copper and zinc were established there. Thus, the $\mathrm{c}$ value from 0.08 to 0.19 were peculiar to phytocenosis with the level of pollution of the bottom deposits with $\mathrm{Cd}^{2+} \mathrm{lower}$ than $0.2 \mathrm{mg} / \mathrm{kg}$ (MAC - 0,7 mg/kg), $\mathrm{Cu}^{2+}$ lower than $3 \mathrm{mg} / \mathrm{kg}$ (MAC - $3 \mathrm{mg} / \mathrm{kg}$ ), $\mathrm{Zn}^{2+}$ lower than $20 \mathrm{mg} / \mathrm{kg}(\mathrm{MAC}-23 \mathrm{mg} / \mathrm{kg}$ ). Further increase in the concentration of heavy metals caused the shift of the Simpson's indices towards the direction of increase, i.e. the range of 0.24-0.26. Correlation dependence with a low level of significance was also noted for the connection of $\mathrm{c}$ with the concentration of $\mathrm{Ni}^{2+}$. It should be noted that virtually $\mathrm{Ni}^{2+}$ concentrations that exceeded MAC (4 mg/kg) were not recorded in the experiment. Moreover, a clear dependence regarding $\mathrm{c}$ distribution was not noted in this range. Therefore, it can be assumed that $\mathrm{Ni}^{2+}$ at a concentration lower that MAC does not have a significant influence on the domination of species in phytocoenosis. The same situation was observed for mobile forms of chromium and cobalt.

In the same groups of pollutants, close correlation connections of the Shannon diversity indices of general diversity (H) were noted. Concentrations of $\mathrm{Cd}^{2+}$ from $0.0-0.20 \mathrm{mg} / \mathrm{kg}, \mathrm{Cu}^{2+}-1.0-4.0 \mathrm{mg} / \mathrm{kg}, \mathrm{Zn}^{2+}$ below $20 \mathrm{mg} / \mathrm{kg}$, determined the distribution of $\mathrm{H}$ in the range of $0.8-1$.1. Further increase of the content of pollutants caused the shift of $\mathrm{H}_{\text {for }} \mathrm{Cd}^{2+}$ to the range of 0.4-0.6, for $\mathrm{Cu}^{2+}$ and $\mathrm{Zn}^{2+}-0.6-0.7$. The weak level of correlation connections was noted between the content of the same pollutant groups and the Pielou's Evenness Index (E). In particular, the stability of the Pielou coefficients 
was observed in areas with the concentration of $\mathrm{Cd}^{2+}$ below $0.4 \mathrm{mg} / \mathrm{kg}, \mathrm{Cu}^{2+}-3.0 \mathrm{mg} / \mathrm{kg}, \mathrm{Zn}^{2+}-20 \mathrm{mg} / \mathrm{kg}$. Further increase in the concentrations of pollutants caused the shift of $\mathrm{E}$ to the range of 0.24-0.26

Consequently, significant correlation dependencies between the content of the mobile forms of chromium and cobalt with the main indicators of biodiversity were not identified. Obviously, this is explained by the fact that the excess of MAC according to the corresponding groups of pollutants was not recorded in any of the research points. Therefore, it can be argued that the concentration of mobile forms of chromium and cobalt cations below MAC do not affect the species diversity. The Margalef, Simpson and Sørensen-Dice indices turned out to be sensitive to the content of $\mathrm{Ni}^{2+}$; these indices showed a weak indication of a concentration exceeding $2 \mathrm{mg} / \mathrm{kg}$. Indices of species diversity were sensitive to the content of the following mobile forms: zinc concentrations exceeding $10 \mathrm{mg} / \mathrm{kg}$ (for d) and 20 $\mathrm{mg} 0 \mathrm{~kg}$ (for c, H and E), which all the evaluation criteria (except the Sørensen-Dice index) responded to; copper concentrations exceeding $3 \mathrm{mg} / \mathrm{kg}$, which all the evaluation criteria responded to; cadmium concentrations exceeding $0.2 \mathrm{mg} / \mathrm{kg}$ (for d, c and $\mathrm{H}$ ) and $0.4 \mathrm{mg} / \mathrm{kg}$ (for E), which all the evaluation criteria (except the Sørensen-Dice index) responded to.

It should be pointed out that the species diversity is transformed in the presence of concentrations of zinc, cadmium and cuprum, which amount to $0.87 \mathrm{MAC}, 0.29 \mathrm{MAC}$ and $1 \mathrm{MAC}$ respectively. Therefore, it can be argued that from the point of view of the stability of phytocoenosis development, the corresponding MACs need to be revised and clarified.

Table 2.Correlation relations between the concentration of heavy metals in the bottom deposits and bioindication indicators

\begin{tabular}{|c|c|c|c|c|c|c|c|c|c|c|c|c|c|c|c|c|c|c|}
\hline \multirow[b]{2}{*}{ 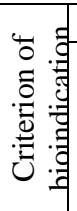 } & \multicolumn{3}{|c|}{$\mathrm{Cd}^{2+}$} & \multicolumn{3}{|c|}{$\mathrm{Co}^{2+}$} & \multicolumn{3}{|c|}{$\mathrm{C} \Gamma^{2+}$} & \multicolumn{3}{|c|}{$\mathrm{Cu}^{2+}$} & \multicolumn{3}{|c|}{$\mathrm{Ni}^{2+}$} & \multicolumn{3}{|c|}{$\mathrm{Zn}^{2+}$} \\
\hline & - & 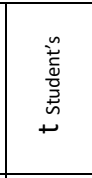 & 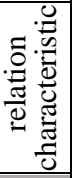 & - & 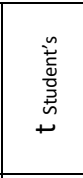 & 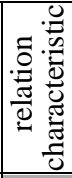 & - & 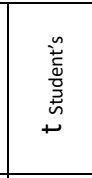 & 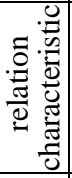 & - & 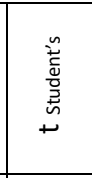 & 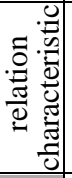 & - & 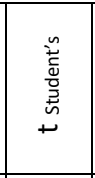 & 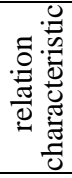 & - & 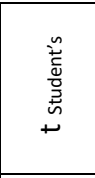 & 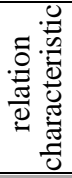 \\
\hline $\mathrm{d}$ & -0.404 & & + & .340 & 654 & + & & & - & -0.290 & 229 & + & -0.396 & 66 & + & -0.497 & -4.207 & + \\
\hline c & 0.490 & 126 & + & 98 & 1.482 & - & & 1.359 & - & 403 & 3.240 & + & 0.283 & 2.169 & + & 0.456 & 3.769 & + \\
\hline $\mathrm{i}$ & -0.105 & -0.775 & - & -0.342 & -2.677 & + & -0.117 & -0.862 & - & 0.297 & 2.287 & + & -0.330 & -2.567 & + & 0.127 & 0.940 & \\
\hline $\mathrm{H}$ & -0.409 & 297 & + & 114 & -0.843 & - & & -0.765 & - & -0.306 & -2.360 & + & -0.193 & -1.448 & - & -0.395 & -3.163 & + \\
\hline $\mathrm{E}$ & -0.291 & -2.233 & + & -0.055 & -0.405 & - & -0.031 & -0.229 & - & -0.265 & -2.018 & + & -0.083 & -0.609 & - & -0.295 & -2.266 & + \\
\hline
\end{tabular}

Note: the value of the relation $r$ on the performance of an attribute is equal to the critical tabular value of t Student's $=1.99$.

\section{CONCLUSIONS}

A diversitological method for determining the class of water quality with the help of indicators of the importance of certain types of higher aquatic vegetation is sensitive to long-term changes in the composition of water and soil. The use of species-indicators allows us to determine the ecological state of reservoirs. Integrated use of this and our other methods will allow us to significantly expand the possibilities of using higher aquatic vegetation in the delayed biological monitoring of hydro ecosystems.

When considering the species composition of the macrophytes of the investigated area, the following conclusions can be made: the combined effect of these factors negatively affects the growth of aquatic plants. There is a decreasing trend in the number of species of macrophytes in areas of increased anthropogenic pressure.

When comparing the results of the chemical and toxicological assessment of water, bottom deposits and coastal soils with the species-recording values, it was identified that the most significant changes in the species composition are manifested at the points of the most considerable anthropogenic pressure confined to the areas affected by sewage of settlements, as well as to the mouth of the Kamianka River, which brings a significant amount of pollutants from the city of Zhytomyr to the water flow of the Teteriv River, while the variation of the species-recording indices is noted when there is a high concentration of heavy metals in the substrate.

Consequently, significant correlation dependencies between the content of the mobile forms of chromium and cobalt with the main indicators of biodiversity were not identified. Obviously, this is explained by the fact that the excess of MAC according to the corresponding groups of pollutants was not recorded in any of the research points. Therefore it can be argued that the concentration of mobile forms of chromium and cobalt cations below MAC do not affect the species diversity. The Margalef, Simpson and Sørensen-Dice index indices turned out to be sensitive to the content of $\mathrm{Ni}^{2+}$; these indices showed a weak indication of a concentration exceeding $2 \mathrm{mg} / \mathrm{kg}$. Indices of species diversity were sensitive to the content of the following mobile forms: zinc concentrations exceeding $10 \mathrm{mg} / \mathrm{kg}$ (for d) and $20 \mathrm{mg} 0 \mathrm{~kg}$ (for c, $\mathrm{H}$ and E), which all the evaluation criteria (except the Sørensen-Dice index index) responded to; copper concentrations exceeding $3 \mathrm{mg} / \mathrm{kg}$, which all the evaluation criteria responded to; cadmium concentrations exceeding $0.2 \mathrm{mg} / \mathrm{kg}$ (for $\mathrm{d}, \mathrm{c}$ and $\mathrm{H}$ ) and $0.4 \mathrm{mg} / \mathrm{kg}$ (for E), which all the evaluation criteria (except the SørensenDice index index) responded to.

It should be pointed out that the species diversity is transformed in the presence of concentrations of zinc, cadmium and cuprum, which amount to $0.87 \mathrm{MAC}, 0.29 \mathrm{MAC}$ and $1 \mathrm{MAC}$ respectively. Therefore, it can be argued that from the point of view of the stability of phytocoenosis development, the corresponding MACs need to be revised and clarified. 


\section{REFERENCES}

1. Bunn S. E., Arthington A. H. 2002. Main principles and ecological consequences of the changed flow patterns for aquatic biodiversity. Management of the Environment, Vol. 30 (4). pp. 492-507. https://doi.org/10.1007/s00267-002-2737-0

2. Cao Y., Bark A. W., Williams W. P. 1996. Measuring the responses of macroinvertebrate communities to water pollution: a comparison of multivariate approaches, biotic and diversity indices. Hydrobiologia, No. 341 (1). pp. 1-19. https://doi.org/10.1007/BF00012298

3. Didukh Ya. P., Pliuta P. G. 1994. Phytoindication of ecological factors. Kyiv : NASU Institute of Botany, 280 p.

4. Fedoniuk T. P. 2018. Morphogenetic analysis of the stability of water macrophytes development in the short-term biomonitoring of water ecosystems of the Polessie of Ukraine. Balanced Nature Using, Vol. 1. pp. 90-98.

5. Feld C.K., da Silva P.M., Sousa J.P., De Bello F., Bugter R., Grandin U., Hering D., Lavorel S., Mountford O., Pardo I., Pärtel M., Römbke J., Sandin L., K.B. Jones, Harrison P. 2009. Indicators of biodiversity and ecosystem services: a synthesis across ecosystems and spatial scales. Oikos, Vol. 118 (12). pp. 1862-1871. https://doi.org/10.1111/j.1600-0706.2009.17860.x

6. Folke C., Nyström M., Peterson G., Bengtsson J., Walker B., Norberg J. 2003. Response diversity, ecosystem change, and resilience. Frontiers in Ecology and the Environment, No. 1 (9). pp. 488-494. https://doi.org/10.1890/15409295(2003)001[0488:RDECAR]2.0.CO;2

7. Gotelli N. J., Colwell R. K. 2001 Quantifying biodiversity: procedures and pitfalls in the measurement and comparison of species richness. Ecology letters, Vol. 4 (4). pp. 379-391. https://doi.org/10.1046/j.1461-0248.2001.00230.x

8. Kovalchuk I. P. Complex analysis of the state of river systems, their functioning and transformation processes. www. channel2012. $\mathrm{ru} / \mathrm{statyi} /$ Kovalchuk. doc. (date of reference: 01.11.2014).

9. Logan P., Furse M. 2002. Preparing for the European Water Framework Directive - making the links between habitat and aquatic biota. Aquatic Conservation: Marine and Freshwater Ecosystems, Vol. 12 (4). pp. 425-437. https://doi.org/10.1002/aqc.535

10. Magurran A. E. 2013. Ecological diversity and its measuremt. Dordrecht: Springer Science \& Business Media, 180 p.

11. Miretzky P., Saralegui A., Cirelli A. F. 2004. Aquatic macrophytes potential for the simultaneous removal of heavy metals (Buenos Aires, Argentina). Chemosphere, Vol. 57, No. 8. pp. 997-1005. https://doi.org/10.1016/j.chemosphere.2004.07.024

12. Mishra V.K., Upadhyaya A.R., Pandey S.K., Tripathi B.D. 2008. Heavy metal pollution induced due to coal mining effluent on surrounding aquatic ecosystem and its management through naturally occurring aquatic macrophytes. Bioresource Technology, Vol. 99 (5). pp. 930-936. https://doi.org/10.1016/j.biortech.2007.03.010

13. Munné A., Prat N., Sola C. Bonda N., Riradevall M. 2003. Simple field method of evaluating the ecological quality of coastal inhabited environments in rivers and streams: index QBR. Water Conservation: Marine and Freshwater Ecosystems, Vol. 13 (2). pp. 147-163. https://doi.org/10.1002/aqc.529

14. Muxika I., Borja A., Bal J. 2007. Using historical data, expert judgement and multivariate analysis in assessing reference conditions and benthic ecological status, according to the European Water Framework Directive. Marine Pollution Bulletin, Vol. 55, No. 1/6. pp. 16-29. https://doi.org/10.1016/j.marpolbul.2006.05.025

15. Nagendra H. 2002. Opposite trends in response for the Shannon and Simpson indices of landscape diversity. Applied Geography. 2002. Vol. 22, № 2. pp. 175-186. https://doi.org/10.1016/S0143-6228(02)00002-4

16. Rai U.N., Sinha S., Tripathi R.D., Chandra P. 1995. Wastewater treatability potential of some aquatic macrophytes: removal of heavy metals. Ecological engineering, Vol. 5 (1). pp. 5-12. https://doi.org/10.1016/0925-8574(95)00011-7

17. Raspopov I. M. 2000. Indication capabilities of macrophytes. Hydrobotany - 2000 : abstracts of the 5th all-Russian conference on aquatic plants. Borok, pp. 204-205.

18. Romanchuck L. D., Fedonyuk T. P., Fedonyuk R. G. 2017. Model of influence of landscape vegetation on mass transfer processes. Biosystems Diversity, Vol. 25, Issue 3. P. 203-209. DOI: https://doi.org/10.15421/011731

19. Romanchuk L., Fedonyuk T., Pazych V., Fedonyuk R., Khant G., Petruk A. 2018. Assessment of the Stability of Aquatic Ecosystems Development on the Basis of Indicators of the Macrophytes Fluctuating Asymmetry. Eastern-European Journal of Enterprise Technologies, Vol. 4, No 11 (94). pp. 54-61. https://doi.org/10.15587/1729-4061.2018.141055

20. Savitskaia K. L. 2014. Evaluation of the ecological state of minor rivers based on the biological index of macrophytes. Reporter of BSU, Chemistry. Biology. Geography, No. 3, pp. 22-27.

21. Spellerberg I.F. 2005. Monitoring ecological change. Cambridge: Cambridge University Press, 412 p. https://doi.org/10.1017/CBO9780511614699

22. Zhukova A. A., Mastitskii S. E. 2014. Bioindication of the quality of natural environment. Minsk : BGU, 112 p. 